simple. It is fairly certain that various regularities in the movements of the planets were also perceived and resulted in expectations, and ancient Assyrian inscriptions testify to a fairly advanced knowledge of planetary periods. A remarkable change in outlook took place when warring little countries were absorbed in the Persian Empire, because the old astrological omens of lucky for Akkad and unlucky for Elam lost all significance. Then astronomers were no longer ignorant earthlings deciphering from the sky messages for the times, and as a consequence the study of the stars and planets became more precise. Some of the scanty inscriptions of the following centuries of rule by the Persian and the Seleucid kings show that a greatly increased knowledge of the periods of revolution of the planets existed, and ephemerides have been found for different years, up to the beginning of the Christian era. Babylonian astronomy attained a more perfect form of theoretical knowledge in the last century B.C., of which various examples are given, and it presents an admirable system of theoretical knowledge, though it is entirely devoid of any physical interpretation. Even the planets were not solid bodies moving in their orbits but mere luminaries wandering along the firmament with unravelled regularity. The cause of this restricted character was due to the priests, whose astronomical work was service to the gods. A further step was necessary if structural theory is regarded as an essential characteristic of theoretical science, and this step was taken by the Greeks.

The Greeks cannot be said to have been great astronomers if we are to judge them from the amount of their observations and detailed knowledge of the heavenly bodies; but, on the other hand, they developed a geometrical way of thinking as an excellent system of demonstrable truths, and this was fit to become the basis of a future higher state of astronomy. The determination of the relative distances of the sun and moon by Aristarchus affords an example of their attitude towards the heavenly world, dealing with its orbs as objects of geometry. In consequence of the conquests of Alexander the Great and the mergence of the Greek and Oriental world which introduced the Hellenistic era, the Greeks gained access to the observational results of the Babylonians. As a result, it was now possible to fill in their geometrical world scheme by exact data on periods and inequalities, and the outcome was the theory of epicycles in which, Prof. Pannekoek believes, we may be said to have reached our goal true astronomical science. "There is," he says, "a conception of science which considers only the latest truth as real, true science. It sees the epicycle theory as a primitive erroneous system, to be superseded 1,700 years later by the true world system." Regarding it from the historical point of view, the epicycle theory represents correctly the relative motions of the planets in their circular orbits, only the original assumptions as to the zero point of the motions requiring subsequent corrections. "It is scientific theory in the strictest sense of the word, systematization of observational facts in a world structure suited to the computation and prediction of future events." The study of the history of science-not only of astronomy shows how important is this stage in the growth of knowledge; though conditioned by the social development of the time, yet as the outcome of observation and thought throughout the centuries, it becomes the starting-point of later progress towards modern science. This affords an explanation of the fact that at a comparatively early time astronomy was able to rise to the high rank of a science when knowledge in other realms of natural phenomena had not risen above the stage of technical experience.

\section{GEOLOGICAL ASPECTS OF CLAY MINERALOGY}

A MEETING of the Clay Minerals Group of the A Mineralogical Society, held in the apartments of the Geological Society of London, Burlington House, London, W.1, on November 2, 1951, was devoted to a discussion on geological aspects of clay mineralogy. Dr. G. Nagelschmidt (Sheffield) occupied the chair at both morning and aftermoon sessions.

Prof. P. G. H. Boswell (Imperial College of Science and Technology, London), in the introductory paper (read in his absence by S. E. Coomber), reviewed the contributions made by clay mineralogists to the study of the diagenesis of sediments. Progress towards the assessment of the character of the clay mineral assemblages in some of the major stratigraphical divisions was summarized, and differences between the results obtained by various workers noted. After discussing the problem of shale formation, Prof. Boswell concluded by outlining some problems, the solution of which awaits more intensive application of clay-mineralogical techniques to geological research. In the discussion, general agreement as to the many problems awaiting solution was expressed, and the contributions which can be made by clay mineralogists were emphasized.

In a systematic petrographic study of the argillaceous rocks associated with the principal sedimentary facies ${ }^{1}$, M. Georges Millot (Nancy) has found that kaolinitic minerals are characteristic of the lacustrine or fluviolacustrine continental facies deposited under acid, leaching conditions ; that illite is characteristic of the saline lagoonal and basic continental facies, although attapulgite and montmorillonite appear under calcareous conditions; and that the mineralogical composition of the marine facies is very mixed, in accordance with its origin, but, generally, a mixture of micaceous minerals (mainly illite) with kaolinite predominates. Statistical information on the variation of clay mineralogy with medium, with potash content, with $p \mathrm{H}$, etc., was given by frequency curves and, in summarizing his results, M. Millot directed attention to the problems which have still to be solved. Dr. H. Greene (Rothamsted Experimental Station), in the ensuing discussion, gave an example in agreement with M. Millot's observation of anomalous formation where conditions of deposition are only broadly defined, while Dr. E. W. Russell (University of Oxford) suggested that montmorillonite might be found in soils derived from the Lower Chalk, but not in those from the Upper. The abundance of kaolinite in the acid continental facies was commented upon by Prof. J. H. Taylor (King's College, London), who suggested that, in view of the work of Grim et al. on recent sediments ${ }^{2}$, the absence of montmorillonite from ancient deposits might be due to its disappearance at some post-depositional stage. The conversion of montmorillonite into illite solely by pressure was queried by Dr. D. M. C. MacEwan (Rothamsted Experimental Station), while, in the same connexion, the effect of drying on potassium montmorillonite ${ }^{3}$ was referred to by Dr. Nagelschmidt. 


\section{No. 4303 April 19, 1952}

That changes in the character of the original clay minerals may occur during the three stages in the evolution of sedimentary rocks-deposition, diagenesis and weathering - was pointed out by Prof. Taylor in his review of the recent work on the environmental significance of clay minerals. Some of the outstanding problems were discussed, and Prof. Taylor appealed for more adequate geological data in papers dealing with clay mineralogy. In the discussion, some comments on the occurrence of glauconite were made by I. H. Warren (St. Austell).

In discussing the geochemical significance of deepsea clays, Dr. J. D. H. Wiseman (Natural History Museum) showed that consideration of the sodium potassium ratios in igneous rocks, river water, etc., leads to the conclusion that the high sodium content of the sea can be accounted for only by continuous abstraction of potassium. Recent results have demonstrated that, in the fine fraction of deep-sea deposits, potassium predominates over sodium, although chemically this fraction does not correspond with illite. Dr. Wiseman suggested, therefore, that the major part of the abstraction of potassium takes place on colloidal compounds of silicon, aluminium, iron and manganese. Sources of deep-sea clays were discussed and reasons given why the rate of sedimentation has remained constant with time in certain areas of the deep-sea floor. A lengthy general discussion ensued in which many members participated. The relative solubilities of various potassium and sodium salts, the formation of potash deposits, salt conditions in the Dead Sea, etc., were all dealt with, while the material responsible for the abstraction of potassium was commented upon, both by K. Norrish (Rothamsted Experimental Station) and by D. B. Honeyborne (Building Research Station, Garston). The latter suggested that the X-ray orientedaggregate technique might give further evidence and discussed the possibility of the appearance of intermediate stages in the formation of illite.

The concept of a reaction series to represent the 'weathering' sequence involved in the development of clay minerals from source rocks was developed in a paper by Prof. J. C. Griffiths (Pennsylvania State College), read by S. E. Coomber. The implications of such a sequence lead to similar applications as those of Bowen's reaction series for igneous rocks ${ }^{4}$ in terms of crystallization, petrogenesis and aggradational metamorphism. According to this reaction relation, sedimentary rocks and soils are merely halt-stages in a series from igneous rocks to the final common end-product - 'laterite'. Reversals in the degradational sequence prior to its culmination are explicable in a manner similar to that used for the formation of low-grade metamorphic rocks from sediments. Some doubt was cast on the degradation of illite to kaolinite by Dr. R. W. Grimshaw (University of Leeds), who reported experiments in which illite had been treated with various solutions in an autoclave, where, in the presence of potassium salts, a reversion to muscovite was observed. His conclusion that illite might be formed from sodium-mica led to further discussion with Dr. Nagelschmidt and Mr. Norrish.

R. H. S. Kobertson and A. E. Twedily (Glasgow) described the biogeochemistry of Skye diatomite in which, in addition to diatom frustules, they had found a 'clay material' which, as it gave no $\mathrm{X}$-ray pattern or reaction on differential thermal analysis, they concluded to be an amorphous mixedoxide gel. The chemical composition of this gel was remarkably constant, and its distribution could be related to water-movement conditions at the time of deposition. The authors concluded that this gel, which on account of its composition they termed 'zeolitic', was in all probability the final stage of the gelatinous, ferruginous compounds which adhere to living diatoms and which consist of the elements in their habitat not required for growth of their frustules. In reply to Dr. Nagelschmidt, Mr. Robertson reported that, for chemical analysis, it is possible to dissolve the 'clay material' without affecting the diatom frustules. Dr. R. C. Mackenzie (Aberdeen) queried the attribution of a definite mineral name to an amorphous co-precipitate the composition of which would presumably vary with environmental factors, while Dr. A. Muir (Rothamsted Experimental Station) suggested the use of the usual term for amorphous materials-'allophane'. Mr. Robertson, in reply, stressed the constancy of chemical composition and the difference in composition between this material and 'allophane' as currently used'.

The general geology of the Cornwall region, and in particular that of the St. Austell china-clay deposit, was discussed by L. G. Brown (St. Austell). The types of alteration of the granite masses, the typical products of each, and the type of veins pervading the granite were described. After a brief description of the methods used in mining the clay, the different properties necessary to give a good clay for various applications were reviewed. Dr. N. O. Clark (St. Austell) and Mr. Warren both added comments on different aspects of the geology of the deposit. In reply to Dr. MacEwan, Mr. Warren indicated that the 'glauconite' he had described had been identified by $\mathrm{X}$-ray examination ; but, in showing a thermogram of the material, Dr. Mackenzie commented upon the resemblance to Ballater illite ${ }^{6}$. Commenting on a question by Mr. Norrish, Mr. Robertson mentioned that, in East Africa and Germany, kaolinite, as distinct from fireclay-mineral, is formed by intense sub-aerial weathering.

In describing the clay minerals present in the Oxford Clay, K. E. Seal (London Brick Co.) showed that, in addition to variation in a vertical direction commensurate with change in the depositional layers, considerable variation in clay mineralogy could be found in any one stratigraphical band, lenses and patches having quite a different composition from neighbouring parts. The investigation has been performed mainly using the differential thermal analysis technique, but this has been supplemented by $\mathrm{X}$-ray determinations carried out in collaboration with Mr. Honeyborne, who reported on some characteristics of the minerals observed. Some comments were made by Dr. Nagelschmidt on the clay-organic complexes postulated by Mr. Seal.

Two brief general papers followed. One, by $R$. Greene-Kelly (Rothamsted Experimental Station), described an investigation by $X$-ray and other methods of the clay-organic derivatives of Prof. $H$. Deuel$^{7}$. Neither with freshly prepared samples nor with some supplied by Prof. Deuel has he obtained a. decrease in cation-exchange capacity after esterification and, generally, has been unable to confirm Deuel's results - for example, a reaction reported by Deuel as occurring with benzene was found to be attributable to thiophene. Consequently, considerable doubt arises as to the existence of these derivatives. The other paper, by Dr. V. C. Farmer (Aberdeen), read by Dr. Mackenzie, presented a detailed criticism of the theory of differential thermal analysis proposed by P. L. Arens ${ }^{8}$. Errors both in 
the mathematical treatment and in some of the assumptions made were pointed out, and it was concluded that these vitiated the correctness of the theory as a whole. Due to the lateness of the hour, a paper on "Mineralogy and Petrography of the Ordovician 'Metabentonites' and related Limestones", by C. E. Weaver and Dr. T. F. Bates (Pennsylvania State College), was read by title only.

This discussion left little doubt as to the importance of the contributions being made by clay mineralogists to geology, and especially to sedimentary petrology; but the general note was that the problems yet to be solved far exceed those to which present knowledge supplies an answer. A fitting conclusion, therefore, was the plea of Prof. Taylor that clay mineralogists should in all papers supply the fullest available geological data.

R. C. Mackenzie

${ }^{1}$ Millot, G., Geol. Appl. et Prospect. Minière, 2, Nos, 2, 3 and 4 (1949). ${ }^{2}$ Grim, R. E., Dietz, R. S., and Bradley, W. F., Bull. Geol. Soc. Amer. 60, $1785(1949)$

see Nagelschmidt, G., Imp. Bur. Soil Sci., Tech. Comm. No. 42, 2 (1944).

' Bowen, N. L., J. Geol., 30, 177 (1922); “The Evolution of Igneous Rocks", Chap, 5, 54 (1928).

s Wilkinson, P., Clay Min. Bull., No, 4, 122 (1950).

Mackenzie, R. C., Walker, G. F., and Hart, R., Min. Mag., 28, 704 (1949).

' See Nature, 168, 107 (1951).

\& Arens, P. I., Dissertation, Landbouwhogeschool, Wageningen (1951).

\section{FOOD PROTECTION IN THE UNITED STATES}

T

HE Delaney Committee established in 1950 by

the United States Congress is continuing its inquiry into the use of chemical additives in food processing and into the allied problem of the contamination of foodstuffs by residues from pesticides and detergents. The earlier sessions of this Committee $^{1}$ revealed that much of the experimental work on the toxicity of chemical additives had given results which were far from conclusive. Biochemists and physiologists in the universities and in foodmanufacturing concerns tended to adopt an extremely cautious attitude in their interpretation of these findings; other scientific workers adopted a somewhat different point of view. This division of opinion constituted a challenge to the objectivity of the scientific witness; a challenge which demanded action by an independent body able to discuss the difficult and complex problems in academic calm and with academic freedom.

Thus there came into being in 1951 a Food Protection Committee formed on the initiative of the Food and Nutrition Board of the National Research Council--itself established in 1916 as an offshoot of the National Academy of Sciences for the purpose of providing panels of independent advisers to the United States Government. This Council is representative of more than ninety major scientific societies and includes business men as well as scientific workers and technologists.

The Food Protection Committee has outlined its programme under four headings as follows. (1) It will assemble scientific information on both incidental and intentional chemical additives which are used, or proposed for use, in or on foods and will summarize and evaluate this information and make its conclusions available in usable form to those interested. (2) It will advise and assist industry and Federal and State government agencies in the integration of research on the utilization of chemicals in food production, processing and preservation, and will promote additional research, by existing agencies, which in the opinion of the Committee appears desirable in the public interest. The Committee itself, however, does not propose to conduct or finance research. (3) It will seek to develop guiding principles and standardized procedures essential for safeguarding food. (4) It will encourage and aid in the distribution of accurate scientific information to the general public.

Under the chairmanship of Prof. H. E. Longenecker, dean of the Graduate School of the University of Pittsburgh, the Committee consists of eleven men of science all holding academic appointments in different universities and in different fields-ranging from human pathology and nutrition, through biochemistry and pharmacology to entomology and plant pathology. Four groups have been established (each under the chairmanship of a member of the Committee) to deal with specific inquiries on the following respective subjects : toxicology, pesticides, food technology and chemistry. The groups are composed primarily of men of science in educational posts, with a lesser number drawn from research associations and other bodies. They are assisted by four advisory panels : from industry, from trade associations and research foundations, from government agencies, and from scientific and technical bodies. This relatively complicated structure is designed to ensure, on one hand, objectivity in decisions and, on the other, channels for the present. ation of divergent points of view and interests.

A recently published statement ${ }^{2}$ of the Food Protection Committee gives a broad survey of the problems under discussion and reveals the efforts being made to provide the equivalent of a pharmacopoeia listing the chemical additives in use and their biological effects on experimental animals and on man. This is a project which should prove of permanent value and might well be a fruitful field of international co-operation between scientific workers in Great Britain and their colleagues across the Atlantic.

'Aylward, F., Nature, 168, i48 (1951).

"Food Protection Committee, "Use of Chemical Additives in Foods" (Nat. Res. Council, 2101 Constitution Avenue, Washington 25, D.C., 1951).

\section{ORIGIN AND DISTRIBUTION OF CULTIVATED PLANTS IN SOUTH ASIA}

DLANT breeding in South Asia has in the past largely been limited to selection in local races, which have the great advantage of being closely adjusted by a long process of natural selection to local climatic conditions. Much more than this is now needed. It is necessary to make large collections of both wild and cultivated forms of economic plants, as well as of crossable wild species in the genus. The species itself, and all other species with which it can exchange genes, becomes a gene pool from which desirable combinations can be synthesized by the new techniques now available. The synthesis of new amphidiploids, the induction of advantageous mutations, and the use of embryo culture to make difficult interspecific crosses possible-all these play a part in modern plant breeding. 